\title{
HABAN FAIENCE IN THE COLLECTIONS OF THE BRATISLAVA CITY MUSEUM
}

\author{
Zuzana FranCovÁ \\ Múzeum mesta Bratislavy (Bratislava City Museum) \\ Radničná 1, 81518 Bratislava, Slovakia \\ E-mail: zuzana.francova@bratislava.sk
}

\begin{abstract}
The author analyses the Haban faience collection of the Bratislava City Museum-the oldest existing Slovak museum (founded in 1868). The first part of the text provides a chronological survey of the Haban ceramics acquisitions and informs about their exhibition, presentation and publishing. This is followed by the typology and chronology of the objects. Based on the type and colour of the glaze and the painted decoration as well as their typology, the artefacts are divided into the following groups: the oldest objects from the period before 1700 , objects with other than white-coloured glaze, objects decorated with blue painting influenced by the Delft faience, pharmacy vessels, floor tiles, white-glazed objects from the period 1700-1730, Late or Post-Haban faience and the ceramics with guild emblems. Finally a Haban stove from Malacky castle is mentioned.
\end{abstract}

Keywords: Haban faience, Slovakia, Bratislava City Museum collections, pharmacy vessels, floor tiles, ceramics for guilds

Haban faience forms an important part of Slovakia's cultural heritage. Although many unique objects manufactured on this geographical territory are preserved in renowned museums abroad, mainly in the Czech Republic (Prague and Brno), Hungary (Budapest) and Austria (Vienna), smaller groups of Haban artefacts can also be found in the main public collections of ceramics in Slovakia. Besides the Slovak National Museum (Slovenské národné múzeum) and its branches (Museum of History in Bratislava, Castle Museum Červený Kameň, Museum of Ethnography in Martin), many regional museums should be mentioned, such as the Múzeum mesta Bratislavy (Bratislava City Museum), Záhorské múzeum (Záhorské Museum) in Skalica (Szakolca, former Hungary), Západoslovenské múzeum (West-Slovakian Museum) in Trnava (Nagyszomat, former Hungary), Stredoslovenské múzeum (Central-Slovakian Museum) in Banská Bystrica (Besztercebánya, former Hungary) and Východoslovenské múzeum (East-Slovakian Museum) in Košice (Kassa, former Hungary). ${ }^{1}$

${ }^{1}$ Buganová 2004: 147-152. 


\section{HISTORICAL SURVEY}

Múzeum mesta Bratislavy-The Bratislava City Museum-is the oldest Slovak museum with uninterrupted existence (since 1868). It has a large collection of ceramics, mainly faience from the territory of Western Slovakia, that includes a high quality set of Haban, Late-Haban and Post-Haban faience, together numbering more than 70 items. $^{2}$ With a few exceptions, the objects were acquired by the museum before 1945 and even before 1918 . The oldest acquisitions are documented as far back as 1869, around 1875, and in 18811882. These objects were purchased individually from different, mostly unknown owners. Some of them were acquired from various personalities of local and wider regional importance: the Bishop of Esztergom and Pressburg Provost Ferdinand Knauz (1831-1898) and the Bratislava (at that time Pressburg, Pozsony, Hungary) painter Eduard Majsch (18411904). Several objects came from the possession of the aristocratic Pálffy family. Among the other names of the last owners registered in the old inventory of the museum are the treasurer of Nagyszombat (Trnava, Slovakia) city Franz Németh (or von Némethy?) or the priest Emanuel Wilhelm Schimko (Simko, Šimko) (1791-1875), the author of several religious works, and from 1835 professor at the Evangelical Lyceum in Pressburg. Several objects were acquired by the museum in the period between the two world wars. Since 1945, acquisitions of Haban faience have been only very sporadic. In the second half of the 1960s and in the first half of the 1970s three objects were purchased for the museum by its long-standing curator of arts and crafts Lujza Kresánková (1923-2009). In 1977, one Haban plate was purchased for the museum's ethnographical collection and in the 1980s two pharmaceutical vessels were acquired for the pharmaceutical collection by its curator Mária Antolíková.

Already in the interwar years the Haban faience formed a part of the permanent exhibitions. After 1926, several pieces were displayed on the $1^{\text {st }}$ floor of the Apponyi House in Bratislava, in the room with ceramics. It is difficult to give their exact number, because in the Catalogue of the Bratislava City Museum of 1933 (compiled by Ol'ga Wagnerová and Alžbeta Mayerová) some objects are registered as "Haban", but other evidently Haban works are described simply as a "plate" or a "Renaissance plate". Thanks to Dr. Alžbeta Güntherová-Mayerová, the art historian and former museum curator, photographs of ten Haban ceramic vessels from the museum collection were published in 1938 in the representative publication edited by the Melantrich publishing house in Prague on the occasion of the great exhibition Staré umění na Slovensku (Old Art in Slovakia). ${ }^{3}$ This important cultural event took place the previous year (1937) in the Prague Castle. In 1942 Güntherová-Mayerová included photos of two Haban objects from the museum collection in her book Slovenská keramika (Slovak Ceramics).

In the spring of 1956 (March $21^{\text {st }}-$ April $15^{\text {th }}$ ), an exhibition of Haban ceramics was held in the then museum's display rooms in Mirbach House in Bratislava (today the Bratislava City Gallery). It was probably a reinstallation of the exhibition Moravská a slovenská

2 Francoví 2011: 15-28. In this article other Haban artefacts from the museum's collections are also mentioned (cutlery, inlaid wooden beams from Haban houses).

${ }^{3}$ Š́ourek 1938: 64-65 (text) - No. 964, 974, 987, 996, 997, 1002, 1016, 1017, 1021, 1029. 
habánska keramika (Moravian and Slovak Haban Ceramics) held in Brno the previous year (curators Alena Kudělková and Milena Zeminová). Some of our Haban objects were included in its catalogue.

Since 1973, a smaller set of Haban faience has been presented in the newly created permanent exhibition of the Bratislava City Museum-the Museum of Arts and Crafts in Bratislava, Beblavého street (curator Lujza Kresánková). Pharmaceutical vessels were on display in the Pharmaceutical Museum in the former pharmacy U červeného raka (At the Red Crayfish) in Michalská street No 26. In 1976, the City Museum presented the exhibition Habánska fajansa v slovenských zbierkach (Haban Faience in Slovak Collections).

More than 40 objects were published by a long-time employee of the museum, the ethnographer František Kalesný (1918-2007) in his book Habáni na Slovensku (Habans in Slovakia) in 1981. Some of them are mentioned directly in the text but most of them are just reproduced on full-page high-grade photographs by Tibor Szabó and Ján Dérer.

Several faience objects from our museum are published in the catalogue of the comprehensive exhibition Habánská fajáns 1590-1730 (Haban Faience) presented by the Museum of Decorative Arts in Prague and the Moravian Gallery in Brno (curators Jana Kybalová and Jarmila Novotná) in late 1981 and early 1982 in the Royal Summerhouse Belvedere in Prague.

In 2011, nine objects from our museum appeared in the book Ceramic Art of the Habans published by Novella Könyvkiadó in Budapest as the fourth volume of the book series Ceramic Art of the Carpathian Basin. In the same year, the Haban collection was presented at an international conference in Modra ${ }^{4}$ and subsequently in Budapest, at another conference.

\section{TYPOLOGY AND CHRONOLOGY}

Haban faience objects in the Bratislava City Museum are registered mostly in the collection of applied arts (arts and crafts). Several pieces of guild ceramics are included in the collection of early history. One piece is listed in the ethnographic collection and more than 20 pharmaceutical vessels belong to the pharmaceutical collection. In addition there are 2-3 pieces in the museum's archeological collection. From a typological viewpoint this collection of faience objects can be divided into three groups. The most numerous group consists of bowls and plates. The second group comprises jugs and other kinds of hollow ceramics. Flat decorative ceramics is represented by tiles.

The periodisation of Haban faience is not uniform in the literature. For the older period, the year 1685 is considered as a significant milestone when the Haban collective ownership ceased to exist and the process of their gradual assimilation with the local environment began. J. Kybalová and J. Novotná (1981) have defined the final "Post-Haban" period as the years 1710-1730. I. Pišútová (1981) has defined the Haban period in WestSlovak faience as the end of the $17^{\text {th }}$ century, and has characterised the $18^{\text {th }}$ century (particularly the first two thirds of it) as a Haban-Slovak period.

${ }^{4}$ FrancovÁ 2011: 15-28. 
In foreign literature, particularly Hungarian, the periodisation of Kurt L. Rein approved in 1981 at an international symposium in Germany has been accepted. According to it, the oldest period is before 1685, the classical Haban faience is between the years 1685-1730, the Late-Haban period is between the years 1730-1780, and a Post-Haban or Haban-Slovak period is considered to be mainly in the 19th century. In classifying (not only) our collections, the problem arises of what objects are still to be considered as Haban, and what objects are to be considered Post or Late-Haban, or even Haban-Slovak.

\section{THE PERIOD BEFORE 1700}

Altogether 11 dated Haban faience objects from the $2^{\text {nd }}$ half of the $17^{\text {th }}$ century can be found in the museum's collections. ${ }^{5}$ The earliest one is a rectangular vessel for water-part of a lavabo set dated 1657 (U-1, Fig. 1). ${ }^{6}$ It has a relatively austere decoration in four colours, limited to stylised flower motifs and tendrils, supplemented with a date. Vessels of this type (small lavabo sets) were possibly originally manufactured for Haban physicians and midwives. ${ }^{7}$ The oldest known specimen dated 1609 is preserved in the collections of the Museum of Applied Arts in Budapest. ${ }^{8}$ As for the shape, an analogical vessel dated 1653 was published by Jana Kybalová and Jarmila Novotná as an object from a private collection. ${ }^{9}$ Similar decoration is to be found on a tankard from 1655, belonging to the collections of the Slovak National Museum in the Červený Kameň castle (Vöröskö, former Hungary), as well as on a quadrangular flattened vessel dated 1694 from the Historical Museum of the Slovak National Museum. ${ }^{10}$

The oldest Haban plate in our museum is dated 1671 (U-9, Fig. 2). This plate is the only Haban object in the collection with the rather uncommon motif of a pomegranate. ${ }^{11}$ A plate dated 1673 with the inscription IOHANES MAHOLANY, decorated with three bouquets on a broad rim, in which yellow tulips are dominant (U-10, Fig. 3), originates from the small town of Svätý Jur (Szentgyörgy, former Hungary) near Bratislava. ${ }^{12}$ A plate with similar inscription and decoration, differing only in small details, was first published by Dr. Karl Layer as an object from the collection of Ludwig Ernst. ${ }^{13}$ Two pieces from our collection were manufactured in the 1670s. The small ribbed bowl dated 1675 (U-5, Fig. 4) is a typical example of Haban artefacts influenced by Italian Renaissance

\footnotetext{
${ }^{5}$ Objects are dated: 1657, 1662, 1671, 1673, 1674, 1689, 1692, 1693-2 pieces, 1696 and 1698.

${ }^{6}$ Kalesný 1981: Fig. 183; Kybalová - Novotná 1981: 41, cat. N. 123, 133 - Fig.; Radványi - Réti 2011: 115, Fig. 139.

${ }^{7}$ KaLESNÝ 1981: 209.

${ }^{8}$ LAYER (s.d.): 3 - Fig.; Katona 1974: 33.

${ }^{9}$ Kybalová - Novotná 1981: 40, cat. No. 107.

${ }^{10}$ PIšútová 1981: 291, catalogue No. 12.

${ }^{11}$ Kalesný 1981: Fig. 118; Francová 2011: 19.

12 Šourek 1938: 65, No 1021; Kalesný 1981: Fig. 119; KybalovÁ - Novotná 1981: 49, cat. No. 199; Francová 2011: 19.

${ }^{13}$ LAYER (s.d.): 40. Ridovics 2002: 82, Fig. 12d (No. 1939.58); RADVÁnYi - RÉTI 2011, 153, Fig. 209. According to the information of Anna Ridovics, Johannes Maholany, Baron Szelepcsényi - Pohronec (+ 1699), was a close relative and secretary of the Archbishop of Esztergom Georg Szelepcsényi and also secretary of the Royal office. Ridovics 2008: 240, 250
} 
faience. Analogies can be found in museums in Prague and Budapest and also in private collections. ${ }^{14}$ There is an object in the Museum of Decorative Arts (Umělechoprůmilové muzeum) in Prague dated from the period around 1670, which is similar to the undecorated oval ribbed dish (U-29)..$^{15}$

Several objects originate from the 1690s. A round ribbed plate with a green wreath is from 1692 (U-6). ${ }^{16}$ An undecorated oval dish with a protruding rim in the middle and the initials I. L. is dated 1693 (U-5097). ${ }^{17}$ Plates from 1693 (BRIDA IANOS, U-7) and 1696 (U-8) are classic examples of a symmetrically placed composition, formed by two flower bouquets and a green wreath with the date on the border, and a third bouquet in the middle at the bottom. ${ }^{18}$

Two fragmentarily preserved and reconstructed jugs, acquired from an archeological research in the area of the Devín (Dévény, former Hungary) castle (A-4453, A-6638) also originate from the end of the 17th century. The jug with melon-like ribbing is dated 1682 and is thought to come from Sobotište (Szobotist, former Hungary). A motif of stylized grapes can be seen at the bottom. ${ }^{19}$

\section{OBJECTS WITH OTHER COLOURED GLAZE}

Besides the objects with painted decoration in four colours on a white glaze, there are also three pieces with a differently coloured glaze in our collection.

The second oldest dated Haban object-a small spherical jug from 1662 (U-2, Fig. 5 ) - belongs to the group with a dark cobalt glaze. This was initially considered to be inspired by the Dutch production in Delft. ${ }^{20}$ But, according to Jana Kybalová, the reason for the use of blue glaze was probably the easy access to the extraction of cobalt in the tin and silver mines in Slovakia. ${ }^{21}$ This jug is exceptional for the first known depiction of an animal motif-a stylized deer-that until then was forbidden in the Haban decoration. ${ }^{22}$ The decoration is arranged in horizontal bands with plant and flower motifs, and is painted in white and yellow. Another example is a yellow-glazed pear-shaped jug with a pewter lid dated 1689 (U-4, Fig. 6). It was manufactured in Szobotist and belonged to

\footnotetext{
${ }^{14}$ Ridovics 2002: 81, Fig. 11a.; RÉTI 2007: 40, Fig. 36. Our plate was published by: Kalesný 1981: Fig. 170 and Kybalová - NovotnÁ 1981: 51, cat. No. 220.

${ }^{15}$ Kybalová - NovotnÁ 1981: 48, cat. No. 186; 150 - Fig.

${ }^{16}$ KaLESNÝ 1981: Fig. 171.

${ }^{17}$ KaLESNÝ 1981: Fig. 172.

${ }^{18}$ Kalesný 1981: Fig. 128, 130; KybalovÁ - NovotnÁ 1981: 68 - cat. No. 351.

19 Thanks to the archaeologist Katarína Harmadyová from the Bratislava City Museum who made both objects accessible for me.

${ }^{20}$ Kybalová -Novotná 1981: 37.

${ }^{21}$ Kybalová - Novotná 1981: 37.

${ }^{22}$ Kybalová - Novotná 1981: 44, cat. No. 148; Francová 2011: 17 (Fig.), 19-20. Radványi - Réti 2011:
} 124, Fig. 162. 
Bishop F. Knauz. ${ }^{23}$ Unique in our collections is a plate from 1728 (U-389, Fig. 7). ${ }^{24}$ On a blue glaze it has a dense white and yellow decoration, formed by small tulips arranged in bouquets, and around the bottom a lace motif is painted.

\section{OBJECTS WITH BLUE PAINTING INFLUENCED BY THE DELFT FAIENCE}

Objects in the Delft manner, decorated with a monochrome blue painting, form a smaller group. This type of decoration was applied before and around 1700. In the first two decades of the $18^{\text {th }}$ century, this fashion gradually disappeared although masters repeatedly returned to the blue decoration.

The oldest item of this kind in our collection is a shaving basin (U-27, Fig. 8), probably acquired from the historian Stephan Rakovszky. Its dating is presented differently in the literature. In 1938, Alžbeta Güntherová dated it to the beginning of the $18^{\text {th }}$ century, but in 1942 she published it as a work done after 1655. Similarly, František Kalesný (1981) dated the basin to the period after the mid- $17^{\text {th }}$ century. ${ }^{25}$

The hexagonal bottle with a stylized architectural and plant décor with the inscription IVHANN LAC DVLCI 1674 and a pewter screw lid (U-3) should probably no longer be considered as original Haban work. In the museum's records it was originally listed as a milk bottle, but according to the inscription it more likely served as a bottle for sweet syrup. Bottles of a similar type were also used for oil or other liquid (similar shapes are also known from the silverware of that period). A similar specimen from the collection of Hugo Vavrečka is owned by the Museum of Decorative Arts (UMPRUM) in Prague. ${ }^{26}$ A graphically painted cobalt decor of this kind, as ascribed by Heřman Landsfeld, comes from the workshops in Szobotist. ${ }^{27}$ The signature FK discovered on this bottle seems to refer to Ferdiš Kostka (1878-1951) but the object was acquired by the museum already in the period between 1871 and 1880 .

A very interesting specimen, rare in the museum collection, is a plate dated 1698 , with a dense fine calligraphically painted blue decoration on the rim, in detail supplemented with green (wreath) and barely noticeable yellow dots (E-2938, Fig. 9). ${ }^{28}$ According to the emblems depicted, it could be a butchers' guild plate. An almost identical plate can be found in the collection of the Arts and Crafts section of the Moravian Gallery in Brno, and another one, from the former Lanna collection, in the Museum of Decorative Arts in Prague. On both, there are the same initials AMG and the same date- $1698 .{ }^{29}$ Based

\footnotetext{
${ }^{23}$ Šourek 1938: 65 - No. 987; KybalovÁ - NovotnÁ 1981: 64, cat. No. 315.

Kalesný 1981: Fig. 181; Francová 2011: 20.

${ }^{24}$ Francová 2011: 18 (Fig.), 20 (text).

25 Šourek 1938: 65, No. 1017; Güntherová 1942: Fig. 7; KalesnÝ 1981: Fig. 154.

${ }^{26}$ Kybalová 1995: 50, No. 56.770, cat. No. 206.

${ }^{27}$ Kybalová 1995: 50, No. 41; 51 - Fig.

${ }^{28}$ Francová 2011: 21.

${ }^{29}$ Kybalová - Novotná 1981: 211, No. 404 and 405.
} 
on the comparison with plates from the same period in Hungarian private collections ${ }^{30}$ we can probably assign it to the circle of the Odler workshop in Dechtice, Dejte (former Hungary) or Chtelnica, Vittenc (former Hungary). ${ }^{31}$ A plate with similar cobalt blue decoration dated 1688 was recently found in the Killy Manor House in Častá (Cseszte, former Hungary) near Bratislava. ${ }^{32}$ A plate with the stylized figure of a woman and the initials A V K is dated 1713 (U-12). The blue colour is supplemented here in details also with yellow and green. ${ }^{33}$ The latest dated specimen with purely blue decor is an oval ribbed and wavy-bordered plate of an Italian type from 1724, decorated with a lily of the valley motif (U-28). It is an example of the combination of an Italian shape with a Delft type of decor. ${ }^{34}$ Among the undated objects, a plate with stylized motifs of birds, fruit, leaves and architecture from around 1700 should be mentioned (U-16). ${ }^{35}$

\section{PHARMACY VESSELS}

The pharmaceutical collection of the museum includes more than 20 Haban vessels used for storing medicines. Most of them have a spherical shape with a foot and an upper rim. In the museum records, and also in the literature, they are mostly called "albarellos." All are decorated with a cobalt-blue decor on a white glazing. The decor is formed of symmetric leaves and flowers. The centre space is left empty for an inscription. They are not dated, but they generally originate from the $17^{\text {th }}$ century, particularly from the end of that period. Such vessels of various sizes were produced in Kosolna (Košolná, Slovakia) they were mainly used in monastery and castle pharmacies. Analogical pieces can be found in the private collection of Ignác Bizmayer. ${ }^{36}$ Our older acquisitions were donated in 1960 from the Salvator pharmacy in Bratislava. Some pieces were acquired by a transfer from the pharmacy $U$ červeného raka (At the Red Crayfish) in Michalská street, two pieces were purchased from Prague. The small set of vessels for medicines is now exhibited in the new smaller permanent pharmaceutical exhibition. (Fig. 10).

${ }^{30}$ RÉTI 2007: 62-63, cat. No. 93-95, 97-98.

${ }^{31}$ The Odlers were a family of ceramics makers active on the territory of the north-west part of the Hungarian Kingdom, now Western Slovakia (of Silesian origin-Adler). They settled in the mid-17 ${ }^{\text {th }}$ century in Szobotist and Broczkó (Brodské, Slovakia): later they spread throughout the territory of Western Slovakia, they lived also in Nagylévárd (Vel'ké Leváre, Slovakia), Jókő (Dobrá Voda, Slovakia) and Stomfa (Stupava, Slovakia). Odlers were the first Hungarian noblemen of Haban origin. Christoff Odler worked as ceramics master of Count Pálffy from Erdöd. The Odler products have many special characteristics (among them also decoration with blue colours). They can be found in many important museum collections (Prague, Brno, Budapest).

${ }^{32}$ More about the excavations in Častá: BoreCKÁ 2010: Nr. 4, p. 8-11.

33 Šourek 1938: 65- No. 1016; Kalesný 1981: Fig. 152; KybalovÁ - Novotná 1981: 84, cat. No. $486 ; 234$ - Fig.; RADVÁNYi - RÉTI 2011: 320 - Fig. 482.

${ }^{34}$ KALESNÝ 1981: Fig. 173.

${ }^{35}$ KaLESNÝ 1981: Fig. 165.

${ }^{36}$ Francová 2011: 22; HrdLovičová 2011: 33, 35. 


\section{FLOOR TILES}

The museum's collection also includes four floor tiles with a decorative pattern formed by an illusionary perspective effect created by the combination of different coloured areas. Three of them having an elongated hexagonal shape (U-664-U-666) were donated to the museum by Count Stephan Pálffy between 1871-1880 and they come from the Vöröskö castle near Pressburg (Fig. 11). ${ }^{37}$ A room in this castle was paved with such floor tiles. ${ }^{38}$ The fourth tile (U-35) has a central hexagonal shape. It was said to come from Kosolna, however, many pieces of the same form from the private collection of Ignác Bizmayer were found in Vlčkovce (Farkashida, Farkašín, former Hungary) near Trnava. ${ }^{39}$ Analogies to our tiles can be also found in the Ethnographical Department of the Moravian Museum in $\mathrm{Brno}^{40}$ (a tile dated to the third quarter of the $17^{\text {th }}$ century), in the collections of the Historical Museum of the Slovak National Museums in Bratislava (from the end of the $17^{\text {th }}$ century), ${ }^{41}$ in the Museum of Applied Arts (Iparmüvészeti Múzeum) in Budapest as well as in the Austrian Ethnographical Museum (Österreichisches Museum für Volkskunde) in Vienna. We could also mention the fragmentary preserved tile, found in 1967 during an archaeological excavation in Žižkova Street below the Bratislava castle, as a Haban work (U-640). It is decorated with symmetrical relief motifs of leaves and flowers in blue, yellow and white colours in arched fields.

\section{WHITE-GLAZED OBJECTS FROM THE PERIOD 1700-1730}

In our museum, this rather short period (where 1700 is considered the milestone marking the end of the Haban period) is represented by several plates, bowls and dishes. Three wide-rimmed dishes with a shape resembling a cardinal's hat are characteristic. Their only decor is formed by a green leafy wreath with initials and dating. Plates of this shape are very typical of Renaissance faience and were manufactured also in pewter.

Two dishes have a monogram AW and the date 1701 (U-13 and U-14). According to a handwritten remark in the accessions inventory, these initials are those of Baron Wenkheim from Vel'ké Leváre (Nagylévárd, former Hungary). The third dish has the initials FL and is dated 1709 (U-15). ${ }^{42}$ A plate from 1702 with the initials TW and AMW on the bottom and three bouquets on the wide rim was acquired from the estate of the painter Eduard Majsch (U-18). ${ }^{43}$ An interesting object is a plate from 1707, decorated with small plant motifs and motifs of birds painted on a grey-blue glaze (U-11). ${ }^{44}$ Compared to the plate embellished with

\footnotetext{
${ }^{37}$ WagnerovÁ - Mayerová 1933: 72, cat. No. 783. All four tiles were exhibited together in the museum's interwar exhibition.

${ }^{38}$ PišútovÁ 1981: 28.

${ }^{39}$ Hrdlovičová 2011: 36-37; 30 and 32 (Fig.) - tiles of elongated form from Košolná.

${ }^{40}$ Kybalová-Novotná 1981: 92, cat. No. 552 (Reg. No. 20463); Kalinová 2011: 62, Fig. 13 - Nr. KER.20.511; HrdloviČová 2011: 32 - Fig. 7, 36 - Fig. 18.

${ }^{41}$ Pišútová 1981: 291, cat. Nos. 14 and 15, reg. No. E-5574 and E-5571. Both were found in Farkashida (Farkašín, Vlčkovce).

PodušElová 2013: 291 (Fig. on p. 290)-tile from the Museum of Ethnography in Martin - No. E-1298.

42 Kalesný 1981: Fig. 136, 137.

${ }^{43}$ Kalesný 1981: Fig. 130; Francová 2001: 73-74.

${ }^{44}$ KaLesný 1981: Fig. 149.
} 
motifs of three large stylized tulips, with the inscription LEFI and the date 1711 (U-22), an almost identical piece exists in Hungary. ${ }^{45}$ (Fig. 12) There is a wine tankard from 1711 (U-20) with a fine decor. Its central decorative motif is a pyramidal composition of floral and animal motifs (lions holding a crown, birds). ${ }^{46}$

\section{LATE OR POST-HABAN FAIENCE}

The collection of Post-Haban or Haban-Slovak faience is relatively numerous. These objects were manufactured mostly for village users in the course of the $18^{\text {th }}$ century and partly in the first half of the $19^{\text {th }}$ century. We can follow on them the gradual transformation of the original austere Haban decor and its enrichment by new decorative elements observed in the surrounding environment.

The oldest example and typical representative of this popular Haban-Slovak faience is a plate from 1721 decorated with the central motif of a human figure supplemented by motifs of domestic animals (U-4676, Fig. 13). Besides the traditional domestic animals (cows), a fox and a parrot also appear here. The basic decoration still forms a cobalt-blue painting with a plant decor as a fading memory of Dutch influence. ${ }^{47}$ The closest analogies of motifs and composition from 1710 can be found in the Réti-Krisztinkovich private collection, as well as in the collections of the Museum of Applied Arts in Budapest. ${ }^{48}$

A large egg-shaped jug dated 1742 originates from the estate of Bishop F. Knauz (U-38, Fig. 14) The bottom is reinforced with a brass fitting. The rich painted decoration is arranged in horizontal bands. Within the floral pattern (flowers and leaves) there are stylized animal motifs (deer, hare) and architecture. It has the inscription IANO CHORWAT ${ }^{49}$ A similarly decorated jug from 1772 (with the same motif over the bottom) is in the collection of the Museum of Applied Arts in Budapest. ${ }^{50}$

Among the acquisitions of the interwar period there is a pear-shaped jug with the initials CCP and the date 1765 in a heart-shaped leafy wreath (U-39), believed to refer to Count and Countess Pálffy (Comitissa et Comes Pálffy). ${ }^{51}$ The plate with the initials GK, dated 1751 (U-31), is a strikingly dynamic composition with a pronounced rotating element. Several pear-shaped jugs originate from Szobotist. Among them a jug with a green painted dominant architectonic motif dated 1794 (U-54) should be mentioned. ${ }^{52}$

A later example of the waning of Haban influence is the archaic-looking "owl" (sova) jug with chess-like pattern and the motif of a stylized deer between bouquets of flowers, the inscription IMRO WODA and the date 1823 (U-67). ${ }^{53}$ Among the undated objects, at least two pearshaped jugs with motifs of a yellow stylized deer should be mentioned (U-4548 and U-4549).

\footnotetext{
${ }^{45}$ Katona 1974: 93 (Fig.), 217 (text). Published as the property of Dr. Barnabás Ruszinkó. Our plate was published by: Kalesný 1981: Fig. 151; Kybalová - Novotná 1981: 83, cat. No. 480; RadvÁnyi - Réti 2011: 337 - Fig. 514.

${ }^{46}$ Kalesný 1981: Fig. 195; RadVÁNYi - RÉTi 2011: 325 - Fig. 493.

${ }^{47}$ Kalesný 1981: Fig. 160; RadVÁNYi - RÉTi 2011: 367 - Fig. 553.

${ }^{48}$ RÉTI 2007: 76, cat. No 129 and 130.

49 Š́oureK 1938: 997; Kalesný 1981: 222; FrancovÁ 2011: 25 (Fig.).

${ }^{50}$ LAYER (s. d.): 54 (Fig.).

${ }^{51}$ Kalesný 1981: Fig. 220.

${ }^{52}$ Kalesný 1981: Fig. 225.

${ }^{53}$ Francová 2011: 25 (Fig.).
} 


\section{CERAMICS FOR GUILDS}

A special group of Post-Haban or Haban-Slovak faience comprises objects created for craftsmen. They were manufactured to order from guilds and are marked with emblems of the particular craft.

The oldest depiction of artisan attributes in our collections is on an undated ribbed egg-shaped jug decorated with three coloured flower bouquets with the inscription MARTINVS FRANICK and attributes of the weaving craft (U-19); in the literature it is dated between 1680 and $1690 .{ }^{54}$

Two objects are associated with the guild of Pressburg rope-makers. A relatively simple plate from 1706 (F-249) belongs to the average production. ${ }^{55} \mathrm{~A}$ large jug with a pewter lid dated 1718 (F-229, Fig. 15) is distinctly more luxurious. ${ }^{56}$ It is decorated with a fine rich painting in a horizontal band. Besides the attributes of the craft, the decor consists of a human figure, animal, flower and plant motifs with many small details.

As for other, younger objects of this group, their relationship with Pressburg is not proven. More likely they originate from the rural environment of Western region. A plate of the guild of wheelwrights from 1735 is a high-quality piece (F-247). ${ }^{57} \mathrm{On}$ its rim, cobaltblue plant motifs and three pairs of yellow birds on either side of a stylized tulip alternate. Other objects from the $18^{\text {th }}$ century are a plate of the butchers' guild from 1752 (F-247), a jug of the bootmakers' guild from 1781 (F-232) and a melon-ribbed jug of the harnessmakers' guild from 1786, acquired from the property of Bishop Knauz (F-235, Fig. 16). On the last two mentioned jugs, there is also the motif of two yellow heraldic lions with double entwined tails, holding a leafy wreath or a guild sign.

A bootmakers' jug from 1813 (F-234) could originate from Szobotist. It is decorated with the combination of mangan brown stylized architecture (with an interesting detail of smoking chimneys) and a large polygonal cartouche. Above the text there are bootmakers' tools. ${ }^{58}$ Similar architectonic motifs are also found on a blacksmiths' guild jug from the same year (F-231). The youngest dated object is a wheelwrights' jug from 1834 (F-251).

\section{HABAN STOVE}

Special mention must be made of a unique example in our collection-the Haban ceramic tile stove from a manor house in Malacky (Malacka, former Hungary), glazed in several colours (U-3893). ${ }^{59}$ It belongs to the old museum collection and no information about it is available. It could be generally dated to the $17^{\text {th }}$ century, but a more detailed research and a search for analogies is needed.

\footnotetext{
${ }^{54}$ Kalesný 1981: Fig. 193; KybalovÁ - Novotná 1981: 64, cat. No. 316.

${ }^{55}$ Kalesný 1981: Fig. 142; RadVÁNYI - RÉTi 2011: 274 - Fig. 407.

56 ŠoureK 1938: 64 - Fig. 974; RadVÁNYI - RÉTi 2011: 314-315 - Fig. 475; FranCOVÁ 2011: 26.

${ }^{57}$ Francová 2011: 26, image.

${ }^{58}$ Francová 2011: 27.

${ }^{59}$ Francová 2011: 27 (Fig.).
} 


\section{LITERATURE}

BORECKÁ, Eva

2010: Killyho kúria v Častej [Killy’s Manor House in Častá]. In: Pamiatky a múzeá, Nr. 4, 8-11.

Buganoví, Klaudia

2004: Habánska keramika v zbierkovom fonde Východoslovenského múzea [Haban Ceramics in the Collections of East-Slovakian Museum in Košice]. In: Etnograf a múzeum VII. Remeselná výroba s akcentom na hrnčiarsku, kachliarsku a kameninovú produkciu. Gemersko-malohontské múzeum, Rimavská Sobota, 147-152.

Francová, Zuzana

2001: Pozostalost' bratislavského maliara Eduarda Majscha [Legacy of Edward Majsch, Bratislava Painter]. In: Zborník Mestského múzea Bratislava XIII, Bratislava, 63-92.

2011: Habánske pamiatky v zbierkach Múzea mesta Bratislavy [Haban Antiquities in the Bratislava City Museum Collections]. In: Habáni a habánska keramika. Zborník z medzinárodného odborného seminára, konaného 3. septembra 2011 v Modre, 15-28. SNM-Múzeum L'. Štúra v Modre.

GünTHEROVÁ-MaYerovÁ, Alžbeta

1942: Slovenská keramika [Slovak Ceramics]. Martin, Matica slovenská.

HrdlovičovÁ, Sylvia

2011: Habánska fajansa v súkromnej zbierke Ignáca Bizmayera [Haban Faience in the Private Collection of Ignác Bizmayer]. In: Habáni a habánska keramika. Zborník z medzinárodného odborného seminára, konaného 3. septembra 2011 v Modre, 29-42. SNM-Múzeum L'. Štúra v Modre.

KALESNÝ, František

1981: Habáni na Slovensku [Habans in Slovakia]. Bratislava, Tatran.

KaLINOvÁ, Alena

2011: Sbírka novokřtěnské (habánské) keramiky v Moravském zemském muzeu v Brně [Haban Ceramics Collection in the Moravian Municipal Museum in Brno]. In: Habáni a habánska keramika. Zborníkz medzinárodného odborného seminára, konaného 3. septembra 2011 v Modre, 57-67. SNM-Múzeum L. Štúra v Modre.

Katona Imre

1974: A habán kerámia Magyarországon [Haban Ceramics in Hungary.] Budapest.

Kybalová, Jana

1995: Keramická sbirka Huga Vavrečky [Ceramics Collection of Hugo Vavrečka]. Praha, Kentaur /Polygrafia.

Kybaloví, Jana - NovotnÁ, Jarmila

1981: Habánska fajáns 1590-1730 (exhibition catalogue). Praha, Uměleckoprůmyslové museum.

LAYER, Karl Dr.

s.a.: Oberungarische Habanen Keramik. Editor Ernst Hubsch Berlin-Leipzig-Wien.

Peschel-Wacha, Claudia

2011: Umenie starých majstrov-bratský riad a habánska fajansa v inventári Rakúskeho národopisného múzea (Österreichisches Museum für Volkskunde) vo Viedni [The Art of Old Masters-Haban Faience in the Collection of the Österreichisches Museum für Volkskunde in Vienna]. In: Habáni a habánska keramika. Zborník z medzinárodného odborného seminára, konaného 3. septembra 2011 v Modre, 79-95. SNM-Múzeum L. Štúra v Modre.

PIŠÚtovÁ, Irena

1981: Fajansa [Faience]. Bratislava, Tatran.

PodušElová, Gabriela (ed.)

2013: Slovenské národné múzeum [Slovak National Museum]. Bratislava, Slovenské národné museum.

RADVÁNYi Diána-RÉTI László

2011: Keramické uméní habánů [Ceramic Art of the Habans]. Budapest, Novella Könyvkiadó 2011. (4th volume of the book series Ceramic Art of the Carpathian Basin). 
RÉTi László

2007: Haban Myth 1593-1738. Treasures from Hungarian Private Collections. Budapest.

Ridovics Anna

2002: A Magyar Nemzeti Múzeum habán kerámiái a 17-18. századból [Pieces of Habán Pottery in the Hungarian National Museum]. In: Folia Historica 23/1, 67-87 (English summary: p. 85-87).

2008: VIII-44. Tál, 1673 [Dish, 1673]. In: Mikó Árpád - Verö Mária (eds.): Mátyás király öröksége - Késő reneszánsz müvészet Magyarországon [The Legacy of King Matthias. Late Renaissance Art in Hungary (16th-17th century)]. Volume 1. Budapest: Magyar Nemzeti Galéria, 2008, 240, 241.

ŠOuREK, Karel (ed.)

1938: Umění na Slovensku. Odkaz země a lidu. Soubor dokumentů [Art in Slovakia]. Praha, Melantrich. WagnerovÁ, Ol'ga-Mayerová, Alžbeta

1933: Katalog Muzea mesta Bratislavy. Bratislava 1933.

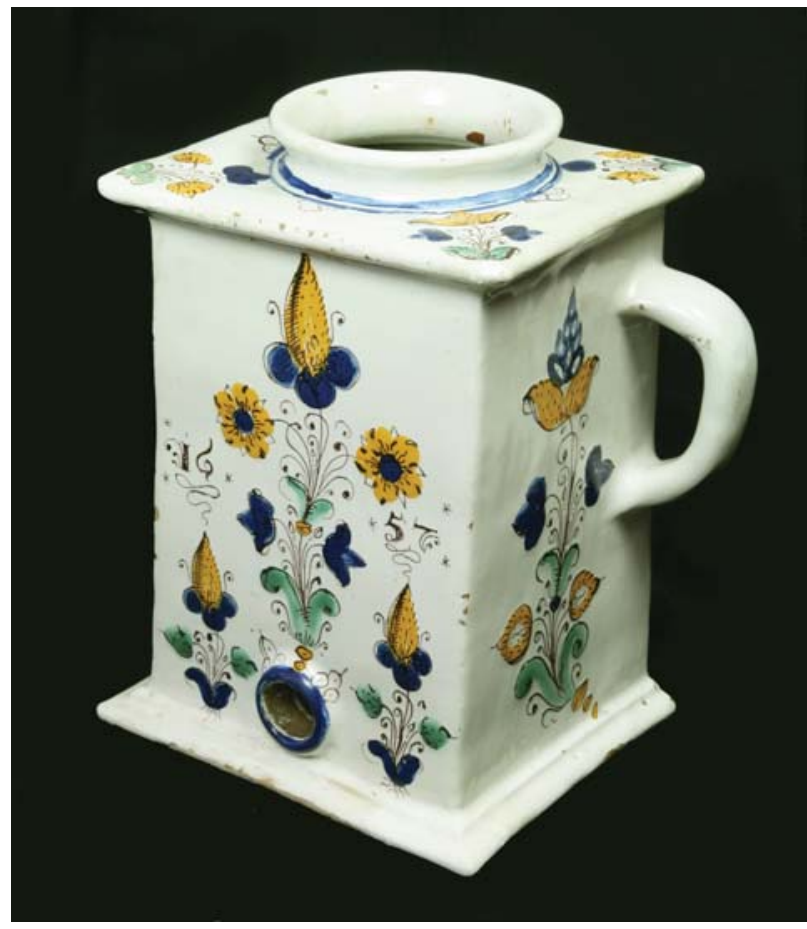

Fig. 1. Vessel for water, 1657. Inv. n. U-1. Photo: L’udmila Mišurová 


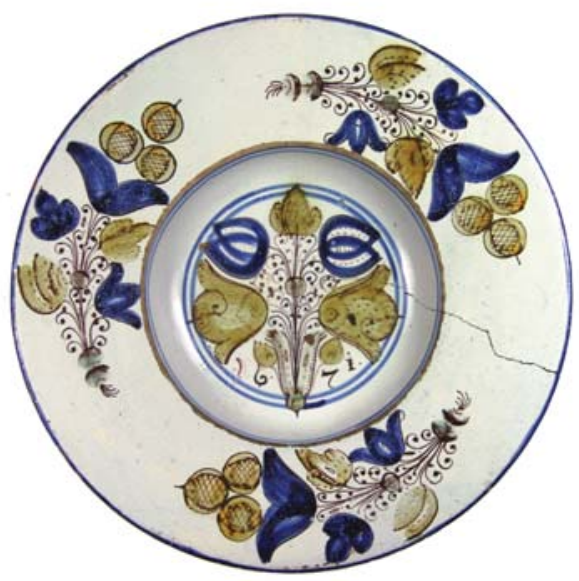

Fig. 2. Plate with motif of pomegranates, 1671. Inv. n. U-9. Photo: L’udmila Mišurová

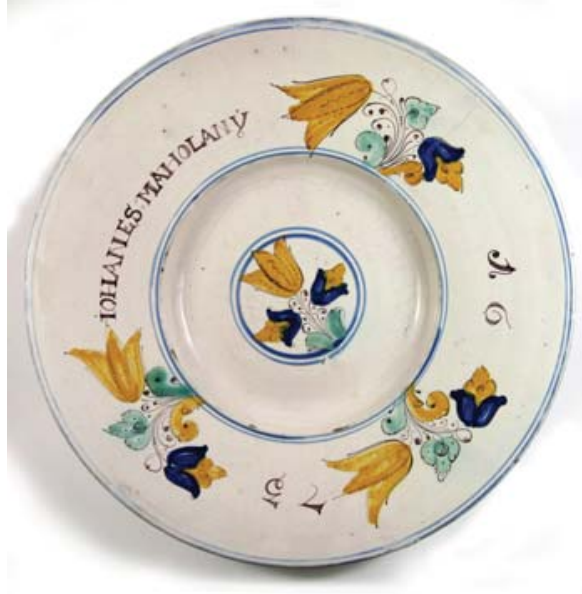

Fig. 3. Plate with inscription IOHANES MAHOLANY, 1673. Inv. n. U-10. Photo: L'udmila Mišurová

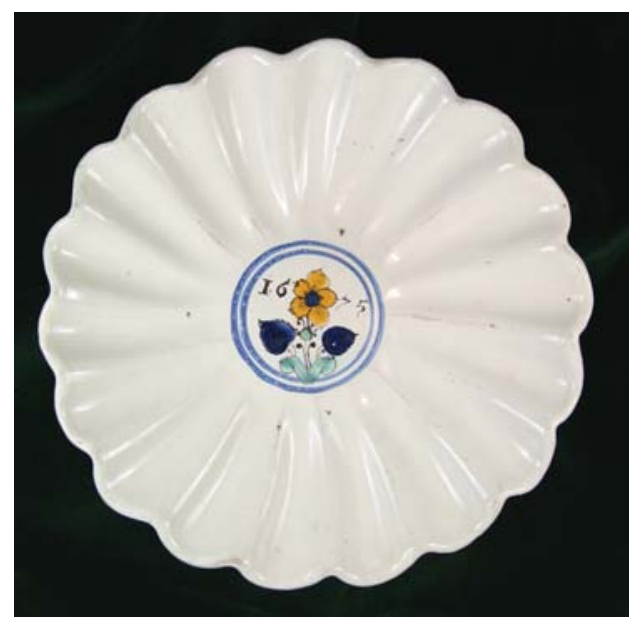

Fig. 4. Ribbed bowl, 1675. Inv. n. U-5.

Photo: L’udmila Mišurová 


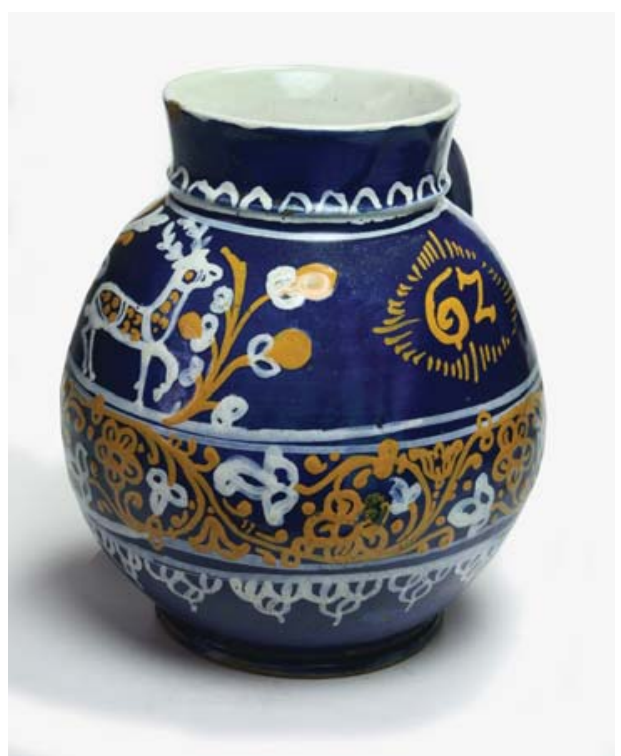

Fig. 5. Jug with cobalt glaze and a motif of deer, 1662. Inv. n. U-2. Photo: Ludmila Mišurová

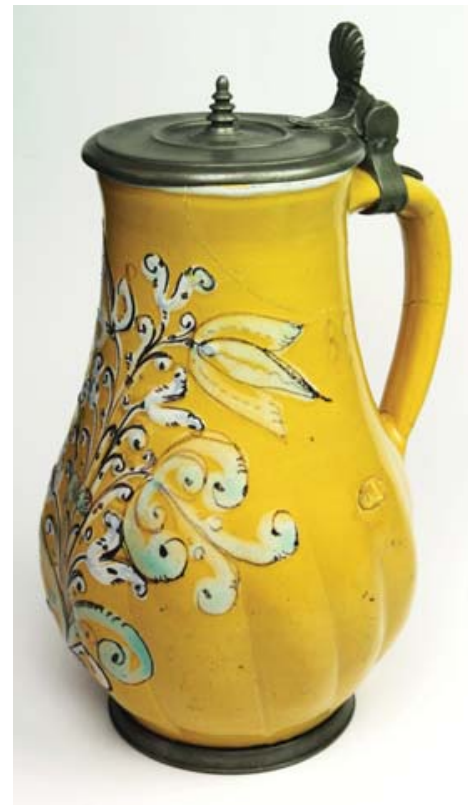

Fig. 6. Jug. Inv. n. U-4. Photo. Marian Lukáč 


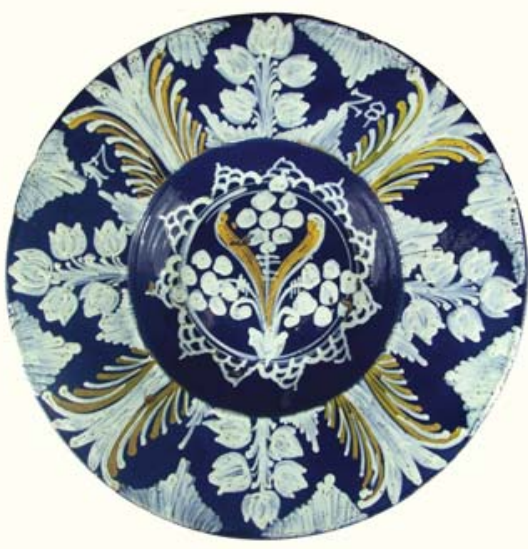

Fig. 7. Plate with blue glaze, 1728. Inv. n. U-389. Photo: L’udmila Mišurová

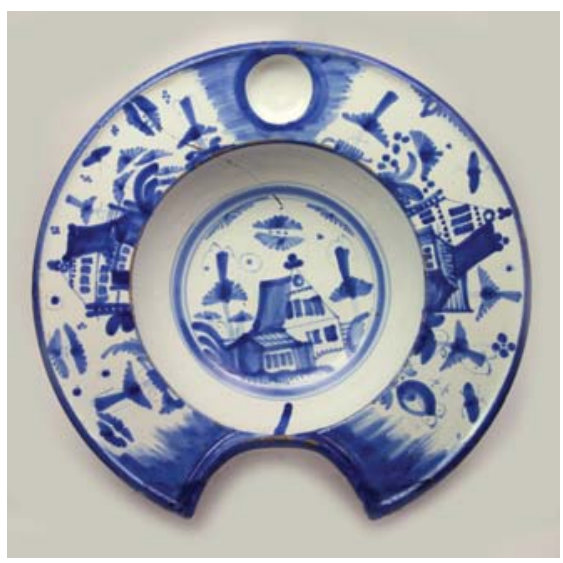

Fig. 8. Shaving basin, after mid $17^{\text {th }}$ century. Inv. n. U-27.

Photo: L’udmila Mišurová

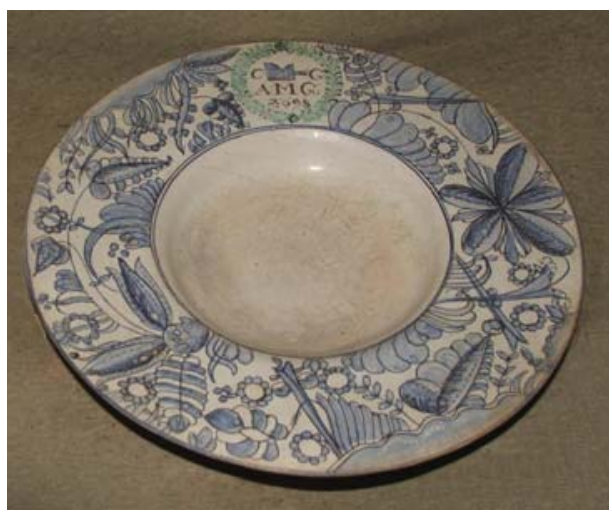

Fig. 9. Plate with blue painting, Odler workshop, Dechtice or Chelnica, 1698. Inv. n. E-2938.

Photo: Soňa Štangová 


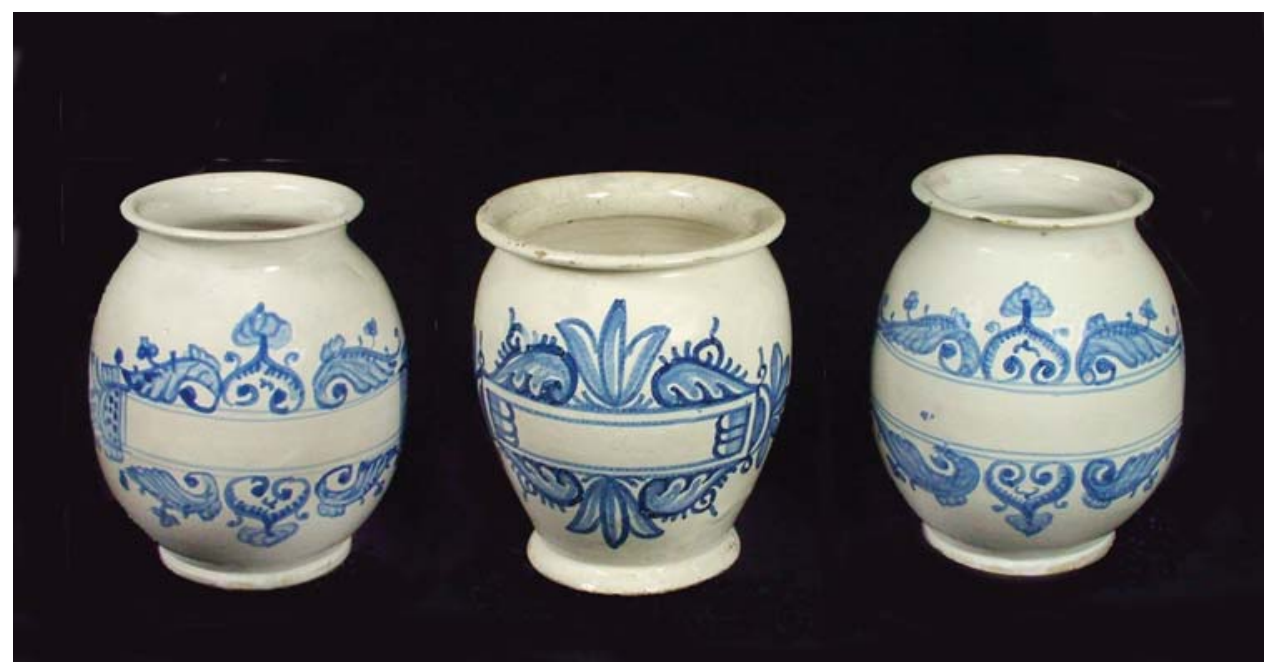

Fig. 10. Pharmaceutical vessels, late $17^{\text {th }}$ century. Inv. n. FA-826, FA-3931, FA-828. Photo: L’uudmila Mišurova

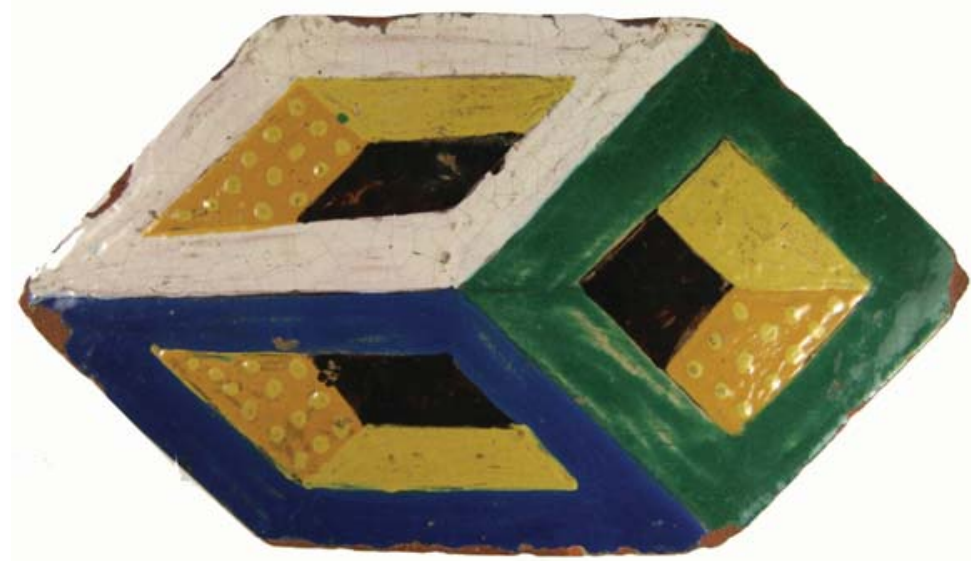

Fig. 11. Floor tile from the Pálffy castle at Vöröskő, third quarter of the $17^{\text {th }}$ century. Inv. n. U-666.

Photo: L'udmila Mišurová 


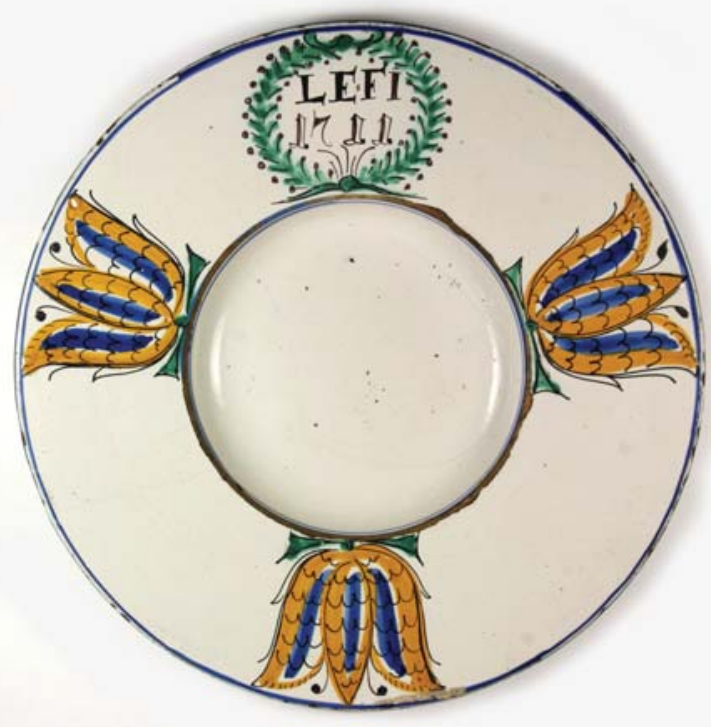

Fig. 12. Plate with tulips, LEFI 1711. Inv. n. U-20.

Photo: L’udmila Mišurová

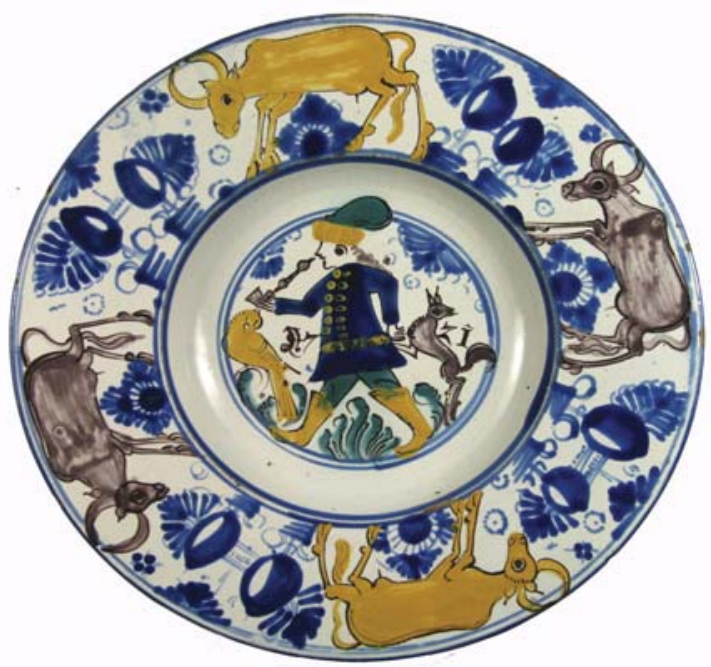

Fig. 13. Plate with a human figure and animals, 1721. Inv. n. U-4676. Photo: Ludmila Mišurová 


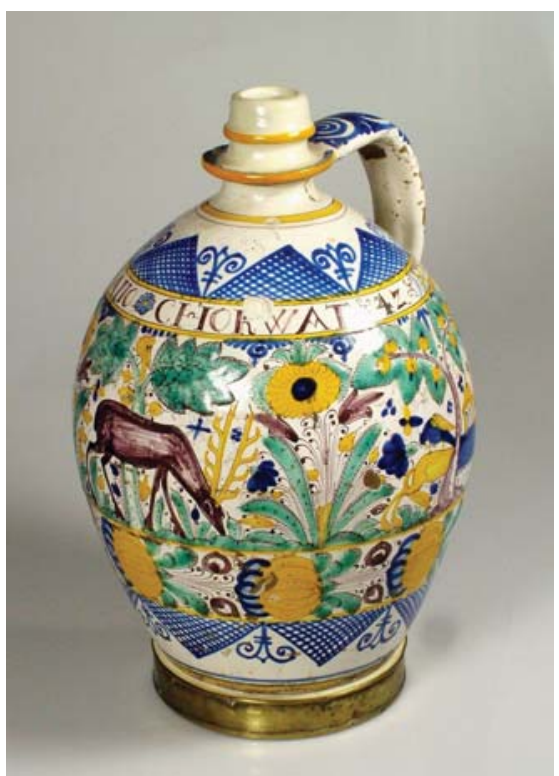

Fig. 14. Jug - dipper with inscription IANO CHORWAT, 1742. Inv. n. U-38.

Photo: L’udmila Mišurová

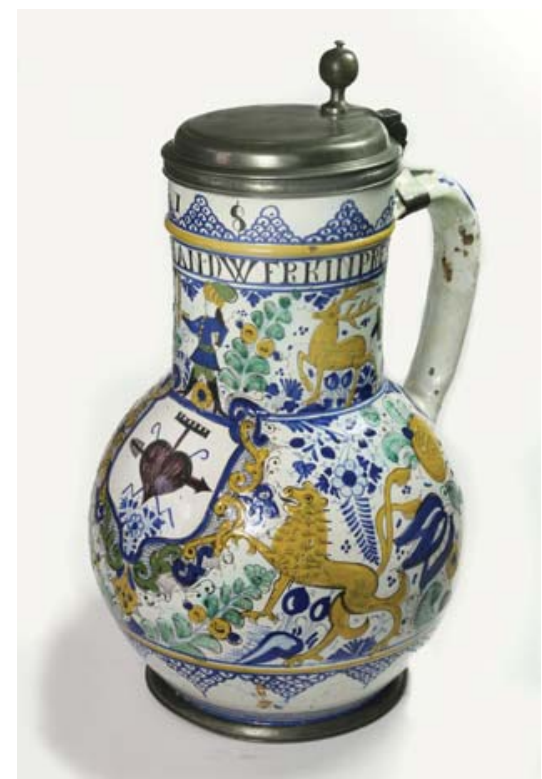

Fig. 15. Jug of the Pressburg rope-makers' guild, pewter lid, 1718. Inv. n. F-229.

Photo: L'udmila Mišurová

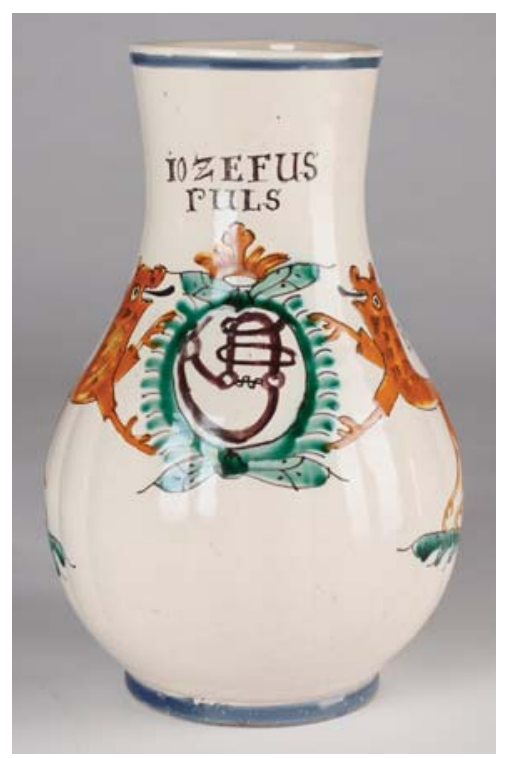

g. 16. Jug of the harness-makers' guild, 1786. Inv. n. F-235. from the property of Bishop F. Knauz. Photo: Marian Lukáč 